\title{
New Potential Use of Protium spruceanum in Hyperglycemia: $\alpha$-Glucosidase Inhibition and Protection against Oxidative Stress
}

\author{
Tatiane R. Amparo, ${ }^{a, b}$ Francine M. Djeujo, ${ }^{b}$ Débora S. da Silva, ${ }^{a}$ Janaina B. Seibert, ${ }^{c}$ \\ Ivanildes V. Rodrigues, ${ }^{d}$ Orlando D. H. Santos, ${ }^{a, c}$ Geraldo C. Brandão, ${ }^{a}$ \\ Paula M. A. Vieira, ${ }^{e}$ Guglielmina Froldi ${ }^{\odot b}$ and Gustavo H. B. de Souza ${ }^{\circledR *, a, c}$ \\ a'Programa de Pós-Graduação em Ciências Farmacêuticas, Universidade Federal de Ouro Preto, \\ 35400-000 Ouro Preto-MG, Brazil \\ ${ }^{b}$ Department of Pharmaceutical and Pharmacological Sciences, University of Padua, 35131 Padua, Italy \\ cPrograma de Pós-Graduação em Biotecnologia, Universidade Federal de Ouro Preto, \\ 35400-000 Ouro Preto-MG, Brazil \\ ${ }^{d}$ Departamento de Farmácia, Universidade Federal de Juiz de Fora, \\ 35010-180 Governador Valadares-MG, Brazil \\ ePrograma de Pós-Graduação em Ciências Biológicas, Universidade Federal de Ouro Preto, \\ 35400-000 Ouro Preto-MG, Brazil
}

\begin{abstract}
The high prevalence of diabetes and obesity encourages research for the development of $\alpha$-glucosidase inhibitors from natural sources. This study evaluated the activity of fractions obtained from Protium spruceanum branches. Anti- $\alpha$-glucosidase activity was investigated in vitro using 4-nitrophenyl- $\alpha$-D-glucopyranoside as the substrate, while free-radical scavenging activity was evaluated by 2,2-diphenyl-1-picrylhydrazyl (DPPH) and 2,2'-azinobis-3-ethylbenzotiazoline6 -sulfonic acid (ABTS) assays. Furthermore, a model of oxidative stress promoted by $\mathrm{H}_{2} \mathrm{O}_{2}$ in fibroblasts was employed, and cell viability was determined by sulforhodamine B. Fractions inhibited $\alpha$-glucosidase activity effectively, highlighting the hydromethanolic fraction (HMF). Quercitrin, isolated from the HMF, was identified by spectroscopy and quantified by a validated high performance liquid chromatography with diode array detector (HPLC-DAD) method and exhibited free radical scavenging activity comparable to the HMF. However, this flavonoid showed low anti- $\alpha$-glucosidase effect, suggesting a synergism effect among several components of the HMF. This proposal is also supported by the docking results obtained by PyRx software. The compounds present in the HMF showed a noncompetitive inhibition at the in silico simulation. Finally, the HMF also protected fibroblasts against cell death induced by oxidative stress. This is the first evidence of the capacity of $P$. spruceanum branches to inhibit $\alpha$-glucosidase activity and to counteract oxidative stress. These results encourage the use of this Brazilian plant against hyperglycemia-correlated diseases.
\end{abstract}

Keywords: Protium spruceanum, Burseraceae, $\alpha$-glucosidase activity, oxidative stress, flavonoids, free-radical scavenging activity

\section{Introduction}

The worldwide changes in caloric intake and diet composition contribute to the increasing prevalence of obesity. ${ }^{1}$ This metabolic disorder leads to low-grade inflammation and chronic oxidative stress which may cause hyperglycemia, leading to type 2 diabetes mellitus (T2DM). ${ }^{2}$

*e-mail: guhbs@yahoo.com.br
Inhibition of $\alpha$-glucosidase is one suitable strategy for the prevention and treatment of various metabolic disorders, such as obesity and T2DM..$^{1,3}$ Moreover, antioxidant activity may contribute to the patient care, slowing the low-grade inflammation associated with these diseases. ${ }^{2}$

$\alpha$-Glucosidase is an intestinal enzyme which catalyzes the cleavage of saccharides to glucose. Thus, its inhibitors are useful to decrease postprandial hyperglycemia. ${ }^{4}$ Efforts have been made to find effective $\alpha$-glucosidase 
inhibitors from natural sources by studying medicinal plants. ${ }^{3,5}$ Protium spruceanum (Benth.) Engler, a Brazilian medicinal plant popularly known as "breu", occurs in Atlantic, Amazon, and Cerrado forests. ${ }^{6,7}$ In traditional medicine, preparations from its resin, leaves, and bark are administered as tea, inhalation and topical applications to treat mainly inflammatory diseases. ${ }^{8}$

Studies of the anti-inflammatory, antinociceptive, and antimicrobial activities of extracts from $P$. spruceanum have already been reported..$^{7-10}$ On the contrary, no ethnopharmacological description of this species for the treatment of T2DM is available in the literature. However, its extracts may have antidiabetic potential due to their high content of phenolic compounds. ${ }^{8}$ In addition, the need for new treatments for T2DM highlights the usefulness of the study of the $\alpha$-glucosidase inhibitory action of $P$. spruceanum, since it has never been investigated.

The present study evaluated the in vitro $\alpha$-glucosidase inhibitory activity of two fractions obtained from P. spruceanum branches. Furthermore, identification and quantification of quercitrin, one of the major bioactive compounds isolated from the hydromethanolic fraction (HMF), were also performed, and then in silico analysis of enzyme interaction with the identified compounds was obtained. Finally, the oxidative stress protection of the most active fraction HMF was investigated.

\section{Experimental}

All solvents were purchased from a commercial supplier (Sigma-Aldrich, St. Louis, USA). The nuclear magnetic resonance (NMR) data were acquired using a Nuclear Bruker Ascend 400 Instrument (Malvern Panalytical, Malvern, UK). The free-radical scavenging activity was evaluated by 2,2-diphenyl-1-picrylhydrazyl (DPPH) and 2,2'-azinobis3-ethylbenzotiazoline-6-sulfonic acid (ABTS) assays (SigmaAldrich, St. Louis, USA). A model of oxidative stress promoted by $\mathrm{H}_{2} \mathrm{O}_{2}$ in fibroblasts was employed, and cell viability was determined by sulforhodamine B (Sigma-Aldrich, St. Louis, USA). The anti- $\alpha$-glucosidase activity was analyzed using 4-nitrophenyl- $\alpha$-D-glucopyranoside as substrate (SigmaAldrich, St. Louis, USA). The absorbance measurements were performed with a Victor X3 2030 Multilabel Reader (PerkinElmer, Waltham, MA, USA). ${ }^{1} \mathrm{H}$ NMR and mass spectra of the isolated compound quercitrin are available in the Supplementary Information section.

\section{Plant material and extraction}

The access for the research was registered at SisGen, Brazilian National System of Genetic Resource
Management and Associated Traditional Knowledge under number A2B5290. Thin branches of P. spruceanum were collected in July 2016 at Lavras, Minas Gerais, Brazil (coordinates $21^{\circ} 17^{\prime} 33.6^{\prime \prime} \mathrm{S}$ and $44^{\circ} 59^{\prime} 15.1^{\prime \prime} \mathrm{W}$, $21^{\circ} 18^{\prime} 11.9^{\prime \prime} \mathrm{S}$ and $\left.44^{\circ} 59^{\prime} 18.8^{\prime \prime} \mathrm{W}\right)$. The speciment was identified by Dr Vivette Appolinário Rodrigues Cabral from the Departamento de Ciências Florestais, Universidade Federal de Lavras. A voucher was deposited in the Herbarium of Universidade Federal de Lavras (16399 HESAL). The branches were dried at room temperature and powdered using a knife mill. The ethanol extract was obtained by ultrasonic-assisted extraction at room temperature of the fragmented material $(300.0 \mathrm{~g})$ with $2 \mathrm{~L}$ of ethanol $95^{\circ} \mathrm{GL}$, and then the hexane fraction (HF) $(2.3 \mathrm{~g}, 11.5 \%)$ and hydromethanolic fraction (HMF) $(18.1 \mathrm{~g}, 90.6 \%)$ were obtained by liquid-liquid partition of the extract, as previously reported. ${ }^{8}$

\section{Quercitrin isolation}

A portion of the HMF ( $2 \mathrm{~g}$ ) was obtained by chromatography on silica gel 60 (70-230 mesh, glass column $2 \times 30 \mathrm{~cm}$ ), eluted with a solvent system of increasing polarity with hexane, ethyl acetate and methanol to afford 52 fractions (HMF.F1 to F52) of $10 \mathrm{~mL}$ each. The fraction HMF.F52 $(200 \mathrm{mg})$, eluted with hexane:ethyl acetate:methanol 30:50:20, was submitted to size exclusion chromatography (Sephadex LH 20, column $2.5 \mathrm{~cm} \times 60 \mathrm{~cm}$, methanol) to afford 26 fractions (SPF. 1 to 26). Fraction SPF.15-19 was applied to preparative high performance liquid chromatography (p-HPLC) with column C-18 Luna $(250 \mathrm{~mm} \times 2.2 \mathrm{~mm} \times 5 \mu \mathrm{m})$, with water (solvent $\mathrm{A}$ ) and methanol (solvent $\mathrm{B}$ ) as mobile phase (from $40 \% \mathrm{~B}$ to $100 \% \mathrm{~B}$, from 0 to $40 \mathrm{~min}$ ) with a flow rate of $8 \mathrm{~mL} \mathrm{~min}^{-1}$ to give Fr.IVT-1 $(5.2 \mathrm{mg})$ at retention time $20 \mathrm{~min}$.

\section{Structure elucidation}

The Fr.IVT-1 structure was proposed by interpretation of its spectroscopic data (UV, NMR, and mass spectrometry (MS/MS)) and comparison with the literature.

\section{Quercitrin (quercetin-3-O-rhamnoside)}

Yellow powder; UV-Vis (methanol) $\lambda_{\max } / \mathrm{nm} 264$, 348; ${ }^{1} \mathrm{H}$ NMR $\left(500 \mathrm{MHz}\right.$, methanol- $\left.d_{4}\right) \delta 6.36(\mathrm{~d}$, $J 1.82 \mathrm{~Hz}, \mathrm{H}-6), 6.19$ (d, $J 2.08 \mathrm{~Hz}, \mathrm{H}-8), 7.36$ (d, $J 1.82$ Hz, H-2'), 6.91 (d, J $8.30 \mathrm{~Hz}, \mathrm{H}-5$ '), 7.31 (dd, $J$ 8.43, $1.95 \mathrm{~Hz}, \mathrm{H}-6$ '), 5.35 (s, H-1"), 3.16-3.17 (m, H-2"), 3.75 (dd, $J$ 9.47, $3.50 \mathrm{~Hz}, \mathrm{H}-3 ")$, 4.21-4.22 (m, H-4"), 3.45 (d, J $1.56 \mathrm{~Hz}, \mathrm{H}-5$ "), 0.94 (d, J $5.97 \mathrm{~Hz}, \mathrm{H}-6$ "); 
liquid chromatography coupled to mass spectrometry (LC-MS/MS) negative mode $m / z 447.32[\mathrm{M}-\mathrm{H}]^{-}, 301.76$ $[\mathrm{M}-\mathrm{H} \text { - rhamnose }]^{-}, 273.23[\mathrm{M}-\mathrm{H} \text { - rhamnose }-\mathrm{CO}]^{-}$, $257.12\left[\mathrm{M}-\mathrm{H}-\text { rhamnose }-\mathrm{CO}_{2}\right]^{-}, 151.20$ $\left[\mathrm{M}-\mathrm{H}-\text { rhamnose }-\mathrm{C}_{8} \mathrm{O}_{3} \mathrm{H}_{6}\right]^{-}$and LC-MS positive mode $m / z 449.41[\mathrm{M}+\mathrm{H}]^{+}, 303.26[\mathrm{M}+\mathrm{H}-\text { rhamnose }]^{+}$.

\section{Quercitrin quantification}

The analysis was performed using a Waters Alliance HPLC-DAD system equipped with a C-18 column (Luna, $4.6 \times 250 \mathrm{~mm}, 5 \mu \mathrm{m}$ particle size, Phenomenex, California, USA) at $30{ }^{\circ} \mathrm{C}$. The mobile phase was comprised by $0.5 \%$ acetic acid in Milli-Q purified water (solvent A) and methanol (solvent B). The flow rate was $1.0 \mathrm{~mL} \mathrm{~min}^{-1}$ and the injected volume was $20 \mu \mathrm{L}$, using the gradient $(10-20 \% \mathrm{~B} / 0-5 \mathrm{~min}, 20-40 \% \mathrm{~B} / 5-10 \mathrm{~min}$, 40-50\% $\mathrm{B} / 10-15 \mathrm{~min}, 50-60 \% \mathrm{~B} / 15-20 \mathrm{~min}$, $60-100 \% \mathrm{~B} / 20-30 \mathrm{~min}, 100-10 \% \mathrm{~B} / 30-35 \mathrm{~min}$, $100 \% \mathrm{~B} / 35-40 \mathrm{~min})$. A wavelength of $254 \mathrm{~nm}$ was used for the analysis. HMF solutions were prepared in methanol at the concentration of $10 \mathrm{mg} \mathrm{mL}^{-1}$. A quercitrin standard solution of $500 \mu \mathrm{g} \mathrm{mL}^{-1}$ in methanol was used to get the range of concentrations $5-250 \mu \mathrm{g} \mathrm{mL}^{-1}$. The analytical method was validated to demonstrate the selectivity, linearity, precision (repeatability), accuracy, and limits of detection and quantification. ${ }^{11}$

\section{Free radical scavenging assays}

The antioxidant activity was evaluated by two photocolorimetric in vitro methods using the free radical indicators 2,2-diphenyl-1-picrylhydrazyl (DPPH), and 2,2'-azinobis-3-ethylbenzotiazoline-6-sulfonic acid (ABTS). The plant fractions, quercitrin and gallic acid (positive control) were solubilized in ethanol $\left(240.0 \mu \mathrm{g} \mathrm{mL}^{-1}\right)$ and different aliquots were diluted to obtain the final solutions ( 0.5 to $40.0 \mu \mathrm{g} \mathrm{mL} \mathrm{mL}^{-1}$ ).

DPPH assay was performed according to the previously described method, with minor modifications. ${ }^{12} 100 \mu \mathrm{L}$ of the DPPH solution at $0.008 \% \mathrm{~m} / \mathrm{v}$ in ethanol were added to each sample and the final volume was adjusted to $240 \mu \mathrm{L}$ with ethanol. The control was obtained using $100 \mu \mathrm{L}$ of DPPH and $140 \mu \mathrm{L}$ of ethanol. All samples were incubated for $30 \mathrm{~min}$ at room temperature $\left(25 \pm 2{ }^{\circ} \mathrm{C}\right)$ protected from light. The absorbance (Abs) was acquired at a wavelength of $490 \mathrm{~nm}$.

The ABTS assay was performed according to the method previously described. ${ }^{13}$ The solution was obtained by mixing ABTS $\left(7.4 \mathrm{mmol} \mathrm{L}^{-1}\right)$ with potassium persulfate $\left(2.6 \mathrm{mmol} \mathrm{L}^{-1}\right)$ and kept for $16 \mathrm{~h}$ at room temperature, protected from light. On the day of analysis, this solution was diluted with ethanol to obtain an absorbance of $0.70( \pm 0.02)$ at $650 \mathrm{~nm}$. Then, $120 \mu \mathrm{L}$ of ABTS were added to the samples. The final volume was adjusted to $150 \mu \mathrm{L}$ with the addition of ethanol. The control was obtained from $120 \mu \mathrm{L}$ of ABTS and $30 \mu \mathrm{L}$ of ethanol. The readings were performed at $650 \mathrm{~nm}$ after incubation of the samples for $6 \mathrm{~min}$ at room temperature $\left(25 \pm 2{ }^{\circ} \mathrm{C}\right)$ and protected from light.

All assays were performed in triplicate. The ability to scavenge free radicals was calculated as the scavenging percentage $(\% \mathrm{I})$, using the formula: $\mathrm{I}(\%)=($ Abs control - Abs sample $/$ Abs control $) \times 100$. The concentration required to obtain a $50 \%$ antioxidant effect $\left(\mathrm{EC}_{50}\right)$ was calculated using GraphPad Prism. ${ }^{14,15}$ Antioxidant activity index (AAI) was calculated as: $\mathrm{AAI}=$ Final concentration of DPPH $\left(\mu \mathrm{g} \mathrm{mL}^{-1}\right) / \mathrm{EC}_{50}\left(\mu \mathrm{g} \mathrm{mL} \mathrm{m}^{-1}\right)$. The antioxidant activity was classified as weak $(\mathrm{AAI}<0.5)$, moderate $(0.5 \leq \mathrm{AAI}<1.0)$, strong $(1.0 \leq \mathrm{AAI}<2.0)$ and very strong $(\mathrm{AAI} \geq 2.0) .{ }^{16}$

$\alpha$-Glucosidase inhibition assay

The $\alpha$-glucosidase inhibition was studied using 4-nitrophenyl- $\alpha$-D-glucopyranoside (p-NPG) as substrate and $\alpha$-glucosidase from Saccharomyces cerevisiae, type I lyophilized powder. Each sample was incubated with $\alpha$-glucosidase and $0.1 \mathrm{M}$ phosphate buffer solution (PBS $\mathrm{pH}$ 6.8) for $10 \mathrm{~min}$ at $37^{\circ} \mathrm{C}$. The reaction started by adding $4 \mathrm{mM}$ p-NPG, and the absorbance values were measured at $405 \mathrm{~nm}$ for $30 \mathrm{~min} .{ }^{17}$ Acarbose $(2 \mathrm{mM})$ was used as positive control. The results were expressed as the half maximal inhibitory concentration $\left(\mathrm{IC}_{50}\right)$ calculated using GraphPad Prism. ${ }^{15}$

\section{Molecular docking}

Molecular docking studies of the compounds identified in the HMF by Amparo et al. ${ }^{8}$ were conducted using the PyRx software, ${ }^{18}$ according to Shahzad et al. ${ }^{19}$ Saccharomyces cerevisiae isomaltase (SCI) (PDB code: 3A4A) $\alpha$-glucosidase crystal structure was obtained from protein data bank (PDB). The 3D structures of the identified compounds (catechin, isoquercitrin, procyanidin B, quercetin-3-O-rhamnoside, quercitrin, and rutin) and acarbose (positive control) were obtained from PubChem data bank. The files were converted to (*.pdb) using Biovia Discovery Studio ${ }^{20}$ prior to docking analysis. The grid boxcentered parametric values were $x=21.2783, y=-0.7737$, $z=18.6460$, and the size values were $x=57.60, y=59.83$, and $z=72.29$. A default exhaustiveness value of 8 was 
used. Graphical depictions were prepared using Biovia Discovery Studio (2.1.0). ${ }^{20}$

\section{Oxidative stress protection}

The effect of the HMF on cell death caused by oxidative stress induced by hydrogen peroxide $\left(\mathrm{H}_{2} \mathrm{O}_{2}\right)$ was evaluated according to the previously described method, with minor modifications. ${ }^{21-23}$ The assay was performed using murine L929 fibroblasts cultured in Roswell Park Memorial Institute (RPMI) 1640 medium containing 10\% fetal bovine serum and gentamicin $\left(60 \mu \mathrm{g} \mathrm{L}^{-1}\right)$, at $37{ }^{\circ} \mathrm{C}$, with $5 \% \mathrm{CO}_{2}$. Cells were added in 96-well plates $\left(1 \times 10^{5}\right.$ cells per well $)$ and incubated for $24 \mathrm{~h}$ for adhesion. Firstly, the cytotoxicity of the HMF (concentrations from 2.00 to $0.03 \mathrm{mg} \mathrm{mL}^{-1}$ in RPMI, $1.0 \%$ dimethyl sulfoxide (DMSO) ) and $\mathrm{H}_{2} \mathrm{O}_{2}$ (from 500.0 to $7.8 \mathrm{mM}$ ) were evaluated in order to select the concentrations to be used in the cytoprotection test. Cells with RPMI and with RPMI 1.0\% DMSO were used as controls. After incubation for $4 \mathrm{~h}$, cell viability was evaluated by the sulforhodamine B assay. ${ }^{24} \mathrm{HMF}$ concentrations that maintained at least $70 \%$ of cell viability in the cytotoxicity test were used to evaluate their effect on oxidative stress. The oxidative stress was induced by $\mathrm{H}_{2} \mathrm{O}_{2}$ at concentrations considered toxic (viability less than 70\%). To assess protection against oxidative stress, cells were treated simultaneously with $\mathrm{HMF}$ and $\mathrm{H}_{2} \mathrm{O}_{2}$. The controls were cells with $\mathrm{H}_{2} \mathrm{O}_{2}$ not treated with the extract and cells without any treatment. After incubation for $4 \mathrm{~h}$, cell viability was evaluated by sulforhodamine B assay. In parallel, the cytotoxic concentration of the HMF for $50 \%$ of the cells $\left(\mathrm{CC}_{50}\right)$ was calculated by a non-linear regression equation using GraphPad Prism. ${ }^{15}$ The selectivity index (SI) was calculated by the ratio $\mathrm{CC}_{50} / \mathrm{IC}_{50}$.

\section{Statistical analysis}

The results are presented as mean \pm standard deviation (SD). The data were evaluated by one-way analysis of variance (ANOVA) using GraphPad Prism $6 .{ }^{15}$ Level of significance was set at $p<0.05$.

\section{Results and Discussion}

P. spruceanum is a Brazilian medicinal plant which exhibits several favorable pharmacological effects due to its high content of phenolic compounds. ${ }^{8}$ The current research evaluated two fractions from extracts of $P$. spruceanum branches to estimate their potential use in hyperglycemic disorders, such as obesity and T2DM.

Analyzed fractions exhibited free radical scavenging activity by DPPH and ABTS assays (Table 1). The ability to scavenge free radicals is important for the treatment of T2DM, since the excess of radicals is associated with alterations of lipid and protein structures, leading to cellular damage typical of obesity and T2DM. ${ }^{2}$

Table 1. Free-radical scavenging activity of the two $P$. spruceanum fractions detected by DPPH and ABTS assays

\begin{tabular}{lcccc}
\hline \multirow{2}{*}{ Sample } & \multicolumn{2}{c}{ DPPH } & & ABTS \\
\cline { 2 - 3 } \cline { 5 - 5 } & $\mathrm{EC}_{50} /\left(\mu \mathrm{g} \mathrm{mL}^{-1}\right)$ & AAI & & $\mathrm{EC}_{50} /\left(\mu \mathrm{g} \mathrm{mL} L^{-1}\right)$ \\
\hline HF & $37.76 \pm 5.91^{\mathrm{a}}$ & $0.8 \pm 0.1^{\mathrm{a}}$ & & $72.84 \pm 9.65^{\mathrm{a}}$ \\
HMF & $8.56 \pm 0.52^{\mathrm{b}}$ & $3.7 \pm 0.2^{\mathrm{b}}$ & & $1.93 \pm 0.29^{\mathrm{b}}$ \\
Quercitrin & $7.60 \pm 0.38^{\mathrm{b}}$ & $3.9 \pm 0.2^{\mathrm{b}}$ & & $5.06 \pm 0.23^{\mathrm{b}}$ \\
Gallic acid & $0.91 \pm 0.03^{\mathrm{c}}$ & $36.5 \pm 1.1^{\mathrm{c}}$ & & $0.52 \pm 0.11^{\mathrm{c}}$ \\
\hline
\end{tabular}

Results are expressed as mean \pm standard deviation $(n=3)$. Different letters mean $p<0.05$ in each column by one-way ANOVA test. DPPH: 2,2-diphenyl1-picrylhydrazyl; ABTS: 2,2-azinobis-3-ethylbenzotiazoline-6-sulfonic acid; $\mathrm{EC}_{50}: 50 \%$ antioxidant effect; AAI: antioxidant activity index; HF: hexanic fraction; HMF: hydromethanolic fraction.

It can be observed that HMF displayed higher scavenging activity than HF (Table 1). A higher activity of polar plant extracts compared to nonpolar ones is frequently observed, since polar solvents favor the extraction of phenolic compounds which are well-known for the antioxidant activity. ${ }^{25}$ Indeed, previous studies have shown that hydromethanolic extracts from $P$. spruceanum branches have a high content of flavonoids and tannins. ${ }^{8}$ These phenolic compounds are among the main natural antioxidants which trap free radicals by mechanisms that involve the catechol group (o-diphenolic group) and other functional groups that are important for antioxidant activity, such as double conjugated bonds and hydroxyl groups. ${ }^{26}$

The antioxidant activity index (AAI) confirmed that the effect of HMF can be considered as very strong (AAI > 2.0), although its $\mathrm{EC}_{50}$ is higher than the gallic acid reference compound (Table 1). This AAI value highlights the antioxidant activity of HMF from $P$. spruceanum branches, especially when compared with fractions derived from orange (Citrus sinensis), that is popularly known as an antioxidant and have an AAI between 1.1 and 1.4. ${ }^{27}$

Furthermore, the fractions of $P$. spruceanum branches inhibited the $\alpha$-glucosidase activity (Figure 1), the main enzyme responsible for the hydrolysis of complex carbohydrates and glucose intestinal absorption. ${ }^{28}$ This experimental finding is the first evidence of the anti- $\alpha$-glucosidase activity of fractions obtained from Protium genus.

Among the fractions, HMF showed higher activity than HF, inhibiting $\alpha$-glucosidase activity at lower concentrations. The higher activity of HMF may be related to the presence of flavonoids, which were detected in large amounts in polar extracts of P. spruceanum. ${ }^{8}$ Several 

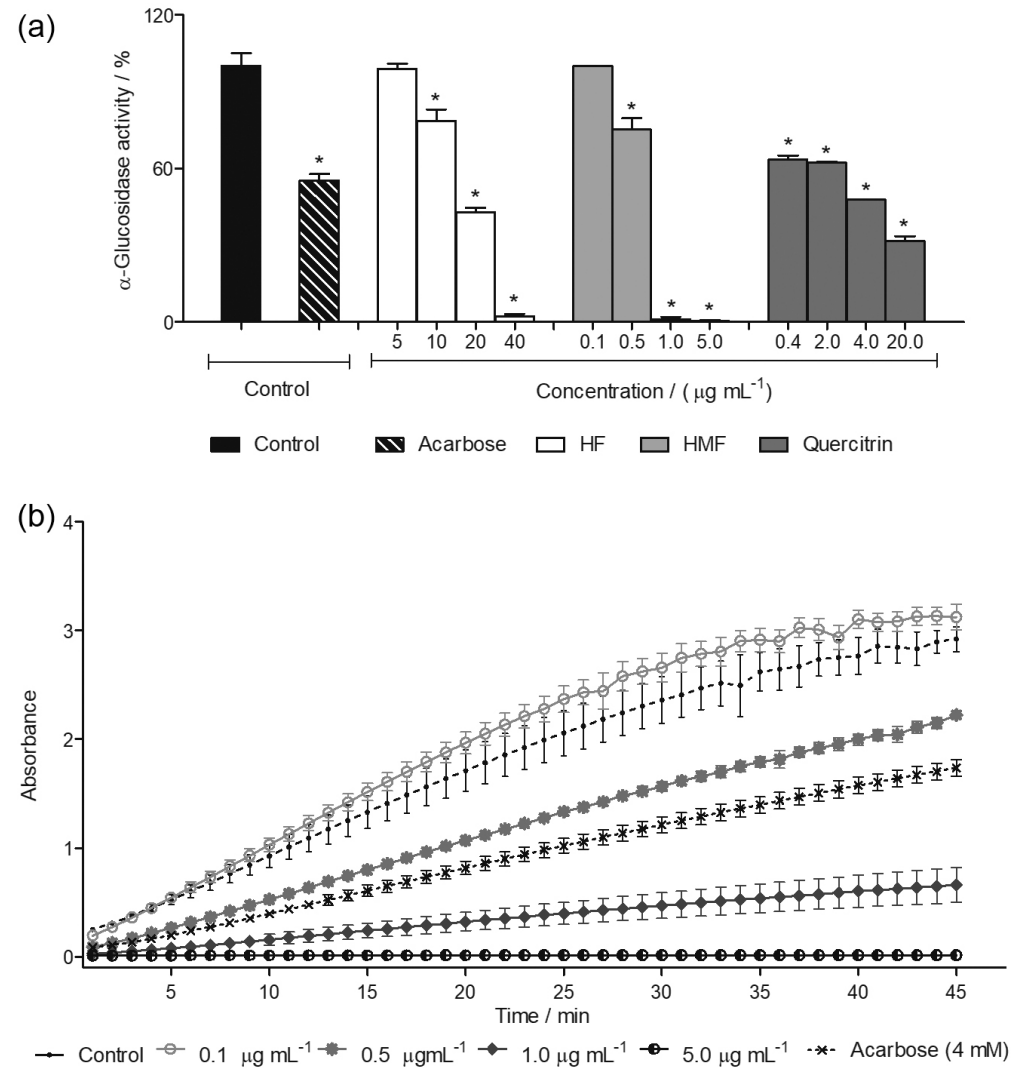

Figure 1. (a) Concentration-dependent inhibition of $\alpha$-glucosidase activity by $P$. spruceanum hexanic and hydromethanolic fractions (HF and HMF, respectively), and quercitrin. (b) Effects of HMF on the $\alpha$-glucosidase kinetics. Acarbose ( $2 \mathrm{mM}$ ) was used as positive control. Control: no treatment. Data are expressed as mean \pm standard deviation $(\mathrm{n}=3-5) . * p<0.05 v s$. control by one-way ANOVA test.

compounds of this class of secondary metabolites have been considered as potential antidiabetic agents due to the anti- $\alpha$-glucosidase activity and the ability to regulate the glucose homeostasis. ${ }^{29}$

In fact, $\mathrm{HMF}$ at $0.5,1.0$ and $5.0 \mu \mathrm{g} \mathrm{mL}^{-1}$ significantly inhibited the $\alpha$-glucosidase activity, as well as the positive control acarbose (Figure 1a). Acarbose can be considered the main $\alpha$-glucosidase inhibitor since it is currently used as a hypoglycemic drug in the treatment and prevention of diabetes. However, the long-term use of acarbose may cause abdominal distention, vomiting and diarrhea, and therefore natural products may represent a choice with minor side effects. ${ }^{30}$

The $\mathrm{IC}_{50}$ values for $\alpha$-glucosidase inhibition were 0.4 and $34.7 \mu \mathrm{g} \mathrm{mL} \mathrm{m}^{-1}$ for HMF and HF, respectively. Thus, both fractions showed a great $\alpha$-glucosidase inhibitory activity when compared to acarbose reference drug, for which an $\mathrm{IC}_{50}$ of $449 \mu \mathrm{M}\left(289 \mu \mathrm{g} \mathrm{mL}^{-1}\right)$ is reported in the literature. ${ }^{31}$ Furthermore, HMF showed a $\mathrm{IC}_{50}$ lower than 52 extracts obtained from several species as reported in the review performed by Kumar et al. ${ }^{3}$ The suitable anti- $\alpha$-glycosidase activity obtained with low concentrations of HMF suggests that this fraction may be appropriate for the treatment of hyperglycemia-correlated pathologies.
The $\alpha$-glucosidase kinetics reveals that the inhibitory effect of the HMF is a time- and concentration- dependent process (Figure 1b). In detail, $\operatorname{HMF}(0.5,1.0$ and $\left.5.0 \mu \mathrm{g} \mathrm{mL} \mathrm{m}^{-1}\right)$ significantly decreased the enzymatic activity during $45 \mathrm{~min}$ of incubation; furthermore, at 1 and $5 \mu \mathrm{g} \mathrm{mL}^{-1}$ it exhibited higher inhibitory activity than $2 \mathrm{mM}$ acarbose (Figure 1b). Other plant derivatives also demonstrated a time- and concentration-dependent inhibition of $\alpha$-glucosidase kinetics, such as extracts from Vernonia amygdalina, used in traditional African medicine to treat diabetes. ${ }^{28}$ Nevertheless, HMF exhibits a greater potential than $V$. amygdalina extracts, which showed $\mathrm{IC}_{50}$ higher than the HMF from P. spruceanum.

Considering the anti- $\alpha$-glucosidase activity of HMF, molecular docking analyses were performed for the compounds previously identified in this fraction by Amparo et al. ${ }^{8}$ All compounds showed fitting binding affinity, interacting with the protein chains mainly by hydrogen bonding (Figure 2). The binding site of the flavonoids was predicted to be close to the active site (glucose binding site), except for the tannin procyanidin B (Figure 2). Thus, the binding of catechin, isoquercitrin, quercitrin, quercetin-3-O-glucuronide and rutin may preclude the entrance of the substrate, preventing the enzyme 
activity. This observation suggests that these compounds may act as noncompetitive inhibitors, in contrast to acarbose that is a competitive inhibitor. ${ }^{32,33}$ Several natural phenolic compounds displayed $\alpha$-glucosidase inhibition by a noncompetitive interaction. Comparing to the competitive type, noncompetitive inhibitors offer the advantage of not being affected by high concentrations of the substrate. ${ }^{34}$

In consideration of the fact that quercitrin exhibited the highest $\alpha$-glucosidase affinity $\left(-10.5 \mathrm{kcal} \mathrm{mol}^{-1}\right)$ among the studied compounds (Figure 2), this compound was isolated and quantified in the HMF. The flavonoid was obtained as a yellow powder and its spectroscopic data (UV, NMR, and MS/MS) were according to that of quercetin3-O-rhamnoside (quercitrin) reported in the literature. ${ }^{35,36}$ Quercitrin has already been isolated from other Protium species, such as $P$. javanicum and $P$. heptaphyllum. ${ }^{37,38}$
However, this flavonoid has not yet been isolated and quantified from $P$. spruceanum.

Validation results of the quantification method for quercitrin showed linearity in the range from 5 to $250 \mu \mathrm{g} \mathrm{mL}^{-1}$ with limits of detection and quantification of 0.62 and $1.89 \mu \mathrm{g} \mathrm{mL}^{-1}$, respectively. The method was precise and accurate since it showed relative standard deviation (RSD) values minor of $5 \%$ (Table 2). In addition, the purity angle (1.267) was lower than the purity threshold (2.284), indicating the specificity of the method. Thus, the validated method was used to quantify quercitrin in the HMF. The quercitrin content in the HMF was $2.6 \pm 0.1 \mathrm{mg} \mathrm{g}^{-1}(0.26 \% \mathrm{~m} / \mathrm{m})$. The amount is higher than that found in the methanolic extract of Hypericum perforatum nonflowering shoots, which showed considerable $\alpha$-glucosidase inhibitory activity correlated with quercetin and kaempferol glycosides. ${ }^{39}$

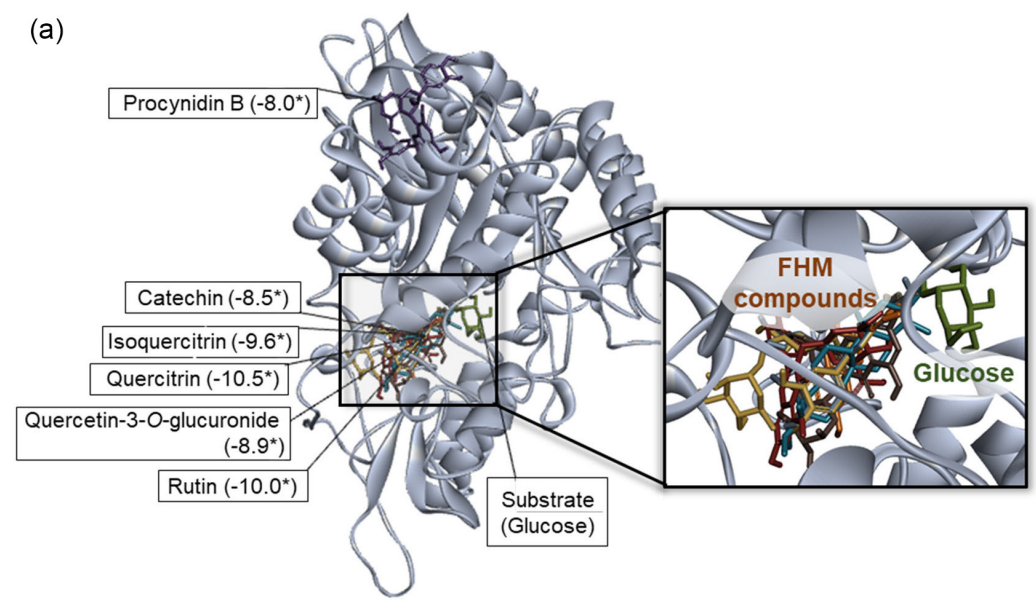

(b)
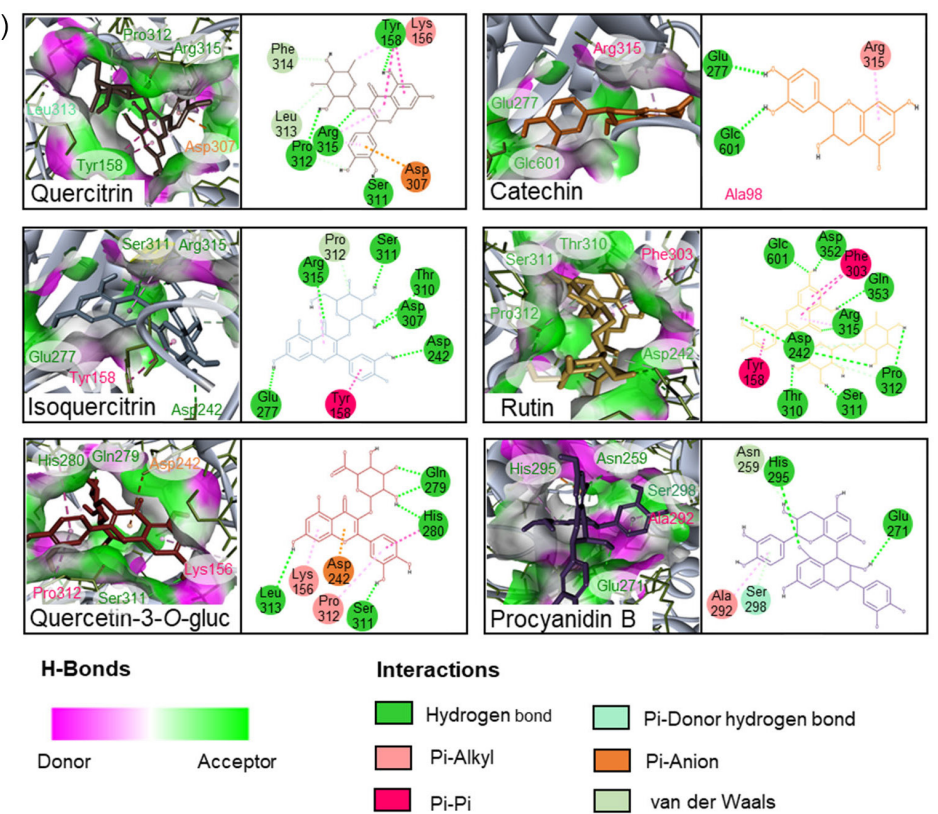

Figure 2. 3D diagram showing the superimposed binding site (a) and diagrams of interactions; (b) of the compounds of the hydromethanolic fraction (HMF) obtained from Protium spruceanum branches with the $\alpha$-glucosidase enzyme. *Binding energy values are in $\mathrm{kcal} \mathrm{mol}^{-1}$. 
Table 2. Validation parameters for quercitrin quantification

\begin{tabular}{|c|c|}
\hline \multicolumn{2}{|c|}{ Specificity } \\
\hline Purity angle & 1.267 \\
\hline Purity threshold & 2.284 \\
\hline \multicolumn{2}{|c|}{ Linearity } \\
\hline$\overline{\mathrm{r}^{2}}$ & 0.9999 \\
\hline Equation & $y=31807 x-2115$ \\
\hline Significance & $p=<0.0001(\mathrm{a} \neq 0)$ \\
\hline Linearity & $p=1.0000$ (linear) \\
\hline \multicolumn{2}{|c|}{ Precision (repeatability) } \\
\hline Concentration / $\left(\mu \mathrm{g} \mathrm{mL}^{-1}\right)$ & RSD \\
\hline 5 & 4.94 \\
\hline 10 & 4.88 \\
\hline 50 & 1.40 \\
\hline 100 & 1.37 \\
\hline 250 & 1.45 \\
\hline Limit of detection / $\left(\mu \mathrm{g} \mathrm{mL} \mathrm{mL}^{-1}\right)$ & 0.62 \\
\hline Limit of quantification / $\left(\mu \mathrm{g} \mathrm{mL} L^{-1}\right)$ & 1.89 \\
\hline
\end{tabular}

Moreover, the isolated quercitrin exhibited free-radical scavenging activity comparable to the HMF (Table 1). The scavenging mechanism of quercitrin includes hydrogen donating of its phenolic hydroxyl groups to stabilize free radicals and thus prevent the oxidation of lipids, proteins, and deoxyribonucleic acid (DNA). ${ }^{40}$ About the anti- $\alpha$-glucosidase effect, quercitrin showed a concentration-dependent inhibition similar to HMF
(Figure 1a). The $\mathrm{IC}_{50}$ value of quercitrin for $\alpha$-glucosidase inhibition was $8.69 \mu \mathrm{g} \mathrm{mL}^{-1}$, equivalent to $19 \mu \mathrm{M}$. The quercitrin $\mathrm{IC}_{50}$ is at least 20 times higher than that of the HMF, indicating that quercitrin is only one of the bioactive compounds responsible for the $\alpha$-glucosidase inhibition demonstrated by the fraction as well as its activity may be greater when combined with other compounds. Thus, the data suggest a possible synergistic effect that is also supported by the docking results, since all compounds showed binding affinity higher or equal than the positive control acarbose $\left(-8.0 \mathrm{kcal} \mathrm{mol}^{-1}\right)$ (Figure 2). The $\alpha$-glucosidase inhibitory activity of other extracts containing quercitrin has already been reported, e.g., Agrimonia pilosa, used to treat T2DM in Chinese traditional medicine, which has also antioxidant activity. ${ }^{41}$

In view of the great anti- $\alpha$-glucosidase activity of HMF, this fraction was also evaluated whether it could protect fibroblasts from oxidative damage induced by reactive oxygen species (ROS) and subsequent cell death. Apoptosis and necrosis due to high oxidative stress generated by hyperglycemia also play a role in the progression of diabetic complications, culminating in tissue injury in the heart, retina and kidneys. ${ }^{42}$ Fibroblasts are present in all these tissues and $\mathrm{H}_{2} \mathrm{O}_{2}$ has been reported to induce apoptosis of these cells. ${ }^{43,44}$ The assay was performed using $\mathrm{H}_{2} \mathrm{O}_{2}$ at 500,250 and $125 \mathrm{mM}$, concentrations able to reduce cell viability below $70 \%$ (Figure $3 \mathrm{a}$ ). HMF decreased cell viability only
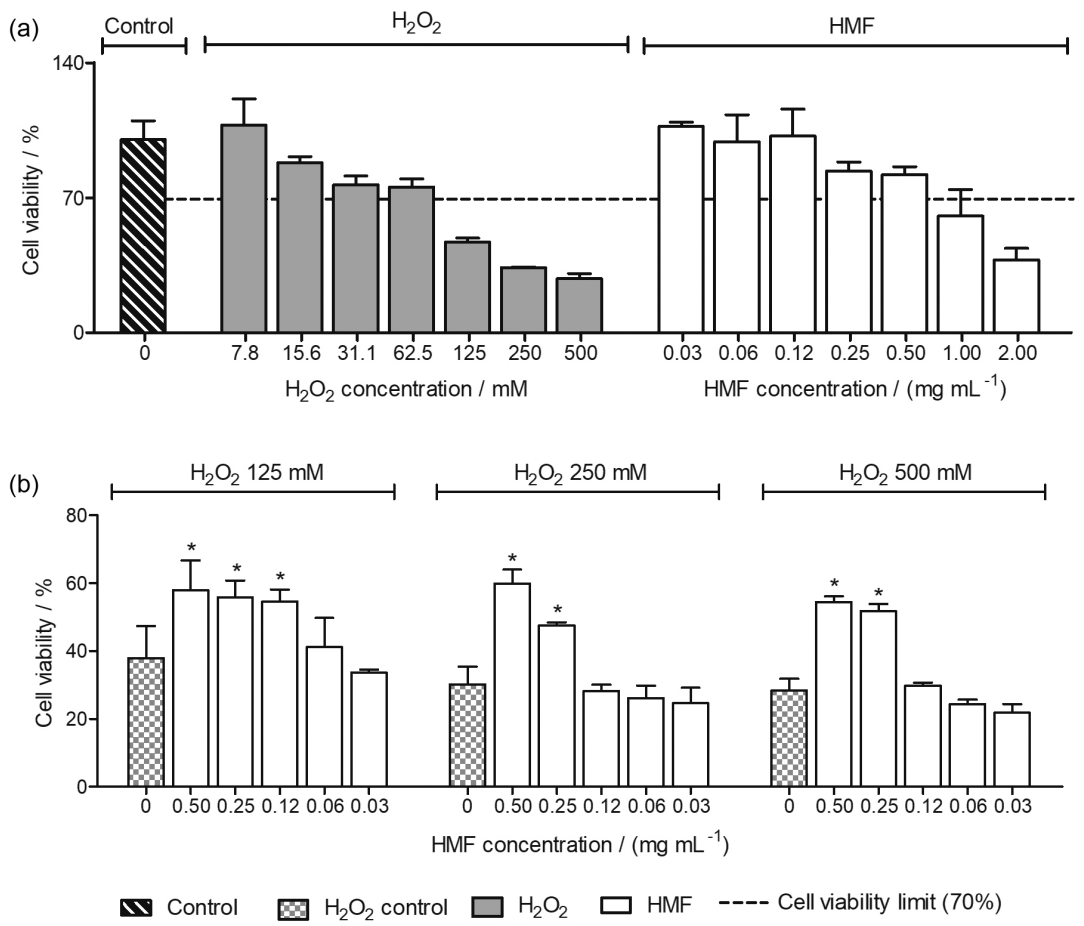

Figure 3. Effects of hydromethanolic fraction (HMF) of Protium spruceanum branches against $\mathrm{H}_{2} \mathrm{O}_{2}$-induced oxidative stress on L929 fibroblasts. (a) Cytotoxicity of $\mathrm{H}_{2} \mathrm{O}_{2}$ or HMF. (b) Cell viability after simultaneous treatment with both $\mathrm{HMF}$ and $\mathrm{H}_{2} \mathrm{O}_{2}$ for 4 h. Control: untreated cells. $\mathrm{H}_{2} \mathrm{O}_{2}$ control: $\mathrm{H}_{2} \mathrm{O}_{2}$-induced cell viability without HMF. Results are expressed as mean $\pm \mathrm{SD}(\mathrm{n}=3)$. ${ }^{*} p<0.05 v s . \mathrm{H}_{2} \mathrm{O}_{2}$ control by one-way ANOVA test. 
at very high concentrations and the $\mathrm{CC}_{50}$ was $1.58 \mathrm{mg} \mathrm{mL}^{-1}$. This low cytotoxicity highlights the use of the HMF as an antioxidant agent and inhibitor of $\alpha$-glucosidase, since the $\mathrm{IC}_{50}$ for both activities was much lower than its $\mathrm{CC}_{50}$.

In these experimental conditions, the HMF treatment prevented the $\mathrm{H}_{2} \mathrm{O}_{2}$-induced cell death (Figure $3 \mathrm{~b}$ ). This cytoprotective effect obtained with the simultaneous incubation of $\mathrm{H}_{2} \mathrm{O}_{2}$ and $\mathrm{HMF}$ suggests that the protection may be due to a direct interaction between $\mathrm{HMF}$ and $\mathrm{H}_{2} \mathrm{O}_{2}$ via free-radical scavenging. ${ }^{25}$ This idea is also supported by the data obtained with DPPH and ABTS assays. The HMF protection against oxidative stress was observed at 0.50, 0.25 and $0.12 \mathrm{mg} \mathrm{mL}^{-1}$ with $125 \mathrm{mM} \mathrm{H}_{2} \mathrm{O}_{2}$ (Figure $3 \mathrm{~b}$ ), while with 250 and $500 \mathrm{mM} \mathrm{H}_{2} \mathrm{O}_{2}$ the HMF inhibited the damage only at higher concentrations, showing a concentration-dependent protective activity. The minimum active concentration of HMF vs. $125 \mathrm{mM} \mathrm{H}_{2} \mathrm{O}_{2}$ was $0.12 \mathrm{mg} \mathrm{mL}^{-1}$, which is at least 13 times lower than the $\mathrm{CC}_{50}$ of the fraction.

This research is the first report showing the cytoprotection against $\mathrm{H}_{2} \mathrm{O}_{2}$-induced oxidative stress of $P$. spruceanum branches. In view of the fact that oxidative stress contributes to the progression of diabetic complications, the cytoprotective effect of HMF also suggests its potential use in T2DM treatment.

\section{Conclusions}

This research shows for the first time the inhibitory activity of polar fractions of $P$. spruceanum branches on $\alpha$-glucosidase activity. Quercitrin, isolated from the hydromethanolic fraction (HMF), exhibits free-radical scavenging activity comparable to the fraction, but with a lower anti- $\alpha$-glucosidase effect, indicating a possible synergism among the various compounds in the mixture. This observation is supported by the docking results, in which identified compounds showed a noncompetitive inhibition, with binding affinity higher or similar to acarbose. In addition to the anti- $\alpha$-glucosidase activity, HMF can also protect fibroblasts against $\mathrm{H}_{2} \mathrm{O}_{2}$-induced oxidative stress. Overall, the data suggest that $P$. spruceanum extracts could be useful to develop new medicines to treat hyperglycemiacorrelated pathologies.

\section{Supplementary Information}

The NMR spectrum used for quercitrin characterization is available free of charge at http://jbcs.sbq.org.br as PDF file.

\section{Acknowledgments}

Fundação de Amparo à Pesquisa de Minas Gerais
(FAPEMIG) (PCI-00359-18), Coordenação de Aperfeiçoamento de Pessoal de Nível Superior (CAPES) and Conselho Nacional de Desenvolvimento Científico e Tecnológico (CNPq), University of Padova (DOR 2019) were acknowledge.

\section{Author Contributions}

Tatiane R. Amparo was responsible for data curation, investigation, visualization and writing original draft; Francine M. Djeujo, Débora S. da Silva, Janaína B. Seibert and Ivanildes V. Rodrigues for data curation, investigation and visualization; Geraldo C. Brandão, Orlando D. H. dos Santos, Paula M. A. Vieira, Guglielmina Froldi and Gustavo H. B. de Souza for formal analysis funding acquisition, project administration, resources, validation and writingreview and editing.

\section{References}

1. Podsędek, A.; Majewska, I.; Kucharska, A. Z.; J. Agric. Food Chem. 2017, 65, 7192.

2. Abdali, D.; Samson, S. E.; Grover, A. K.; Med. Princ. Pract. 2015, 24, 201.

3. Kumar, S.; Narwal, S.; Kumar, V.; Prakash, O.; Pharmacogn. Rev. 2011, 5, 19.

4. Fatmawati, S.; Shimizu, K.; Kondo, R.; Phytomedicine 2011, $18,1053$.

5. Eruygur, N.; Dural, E.; Phytomedicine 2019, 53, 234.

6. Vieira, F. A.; Appolinário, V.; Fajardo, C. G.; Carvalho, D.; Rev. Bras Bot. 2010, 33, 711.

7. Rodrigues, I. V.; Souza, J. N. P.; Silva, A. C. G.; Chibli, L. A. A.; Cabral, V. A. R.; Filho, S. A. V.; Perazzo, F. F.; Guimarães, A. G.; Souza, G. H. B.; Pharmacogn. J. 2013, 5, 6.

8. Amparo, T. R.; Seibert, J. B.; Mathias, F. A. S.; Vieira, J. F. P.; Soares, R. D. O. A.; Freitas, K. M.; Cabral, V. A. R.; Brandão, G. C.; Santos, O. D. H.; Souza, G. H. B.; Vieira, P. M. A.; J. Ethnopharmacol. 2019, 241, 112024.

9. Amparo, T. R.; Rodrigues, I. V.; Seibert, J. B.; Souza, R. H. Z.; Oliveira, A. R.; Cabral, V. A. R.; Vieira, P. M. A.; Brandão, G. C.; Okuma, A. A.; Filho, S. A. V.; Teixeira, L. F. M.; Souza, G. H. B.; Nat. Prod. Res. 2018, 32, 1951.

10. Amparo, T. R.; Rodrigues, I. V.; Seibert, J. B.; Almeida, T. C.; Cabral, V. A. R.; Vieira, P. M. A.; Brandão, G. C.; Oliveira, M. L. G.; Silva, G. N.; Santos, O. D. H.; Filho, S. A. V.; Teixeira, L. F. M.; Souza, G. H. B.; Braz. J. Pharm. Sci. 2020, 56, e18474.

11. International Conference on Harmonization (ICH); $Q 2 A$ (CPMP/ICH/381/95) Validation of Analytical Procedures: Definitions and Terminology; International Conference on Harmonization, 1995, available at https://www.ema.europa. eu/en/documents/scientific-guideline/ich-q-2-r1-validation- 
analytical-procedures-text-methodology-step-5_en.pdf, accessed in June 2021.

12. Sousa, C. M. M.; Silva, H. R.; Vieira Jr., G. M.; Ayres, M. C. C.; Costa, C. L. S.; Araújo, D. S.; Chaves, M. H.; Quim. Nova 2007, 30, 351.

13. Li, X.; Wu, X.; Huang, L.; Molecules 2009, 14, 5349.

14. Chen, Z.; Bertin, R.; Froldi, G.; Food Chem. 2013, 138, 414.

15. Radushev, D.; Prism 5 for Windows, version 5.01; GraphPad Software, USA, 2007.

16. Scherer, R.; Godoy, H. T.; Food Chem. 2009, 112, 654.

17. Froldi, G.; González, D. L.; Rosteghin, F.; Grison, M.; Sut, S.; Dall'Acqua, S.; Sánchez-Mateo, C. C.; Nat. Prod. Res. 2020, 34, 3418.

18. Dallakyan, S.; PyRx Software-Python Presciption 0.8; The Screipps Research Institute, USA, 2010.

19. Shahzad, D.; Saeed, A.; Larik, F. A.; Channar, P. A.; Abbas, Q.; Alajmi, M. F.; Arshad, M. I.; Erben, M. F.; Hassan, M.; Raza, H.; Seo, S.; El-Seedi, H. R.; Molecules 2019, 24, 1511.

20. Biovia, S. D.; Discovery Studio Visualizer 2019 (2.1.0); Dassault Systèmes, San Diego, USA, 2018.

21. Huang, D.; Yin, L.; Liu, X.; Lv, B.; Xie, Z.; Wang, X.; Yu, B.; Zhang, Y.; Int. J. Mol. Med. 2018, 41, 739.

22. Pitz, H. S.; Pereira, A.; Blasius, M. B.; Voytena, A. P. L.; Affonso, R. C. L.; Fanan, S.; Trevisan, A. C. D.; Ribeiro-doValle, R. M.; Maraschin, M.; Oxid. Med. Cell Longevity 2016, 2016, 3403586.

23. Sharifi, R.; Pasalar, P.; Kamalinejad, M.; Dehpour, A. R.; Tavangar, S. M.; Paknejad, M.; Natanzi, M. M.; Nourbakhsh, M.; Ashtiani, H. R. A.; Akbari, M.; Rastegar, H.; Pharm. Biol. 2013, 51, 298.

24. Skehan, P.; Storeng, R.; Scudiero, D.; Monks, A.; McMahon, J.; Vistica, D.; Warren, J. T.; Bokesch, H.; Kenney, S.; Boyd, M. R.; J. Natl. Cancer Inst. 1990, 82, 1107.

25. Sambou, M.; Jean-François, J.; Ndongou Moutombi, F. J.; Doiron, J. A.; Hébert, M.; Joy, A. P.; Mai-Thi, N. N.; Barnett, D. A.; Surette, M. E.; Boudreau, L. H.; Touaibia, M.; Molecules 2020, 25, 2397.

26. Soobrattee, M. A.; Neergheen, V. S.; Luximon-ramma, A.; Aruoma, O. I.; Bahorun, T.; Mutat. Res. 2005, 579, 200.

27. García, B. F.; Torres, A.; Macías, F. A.; Molecules 2015, 20, 20079.
28. Medjiofack Djeujo, F.; Cusinato, F.; Ragazzi, E.; Froldi, G.; J. Pharm. Pharmacol. 2021, rgab057.

29. Pereira, D. F.; Cazarolli, L. H.; Lavado, C.; Mengatto, V.; Figueiredo, M. S.; Guedes, A.; Pizzolatti, M. G.; Silva, F. R.; Nutrition 2011, 27, 1161.

30. Hwang, S. H.; Li, H. M.; Lim, S. S.; Wang, Z.; Hong, J. S.; Huang, B.; J. Evidence-Based Complementary Altern. Med. 2016, 2016, 8983232.

31. Duong, T.; Hang, T.; Pogam, P. L.; Tran, T.; Mac, D.; Dinh, M.; Sichaem, J.; Planta Med. 2020, 86, 776.

32. Yan, J.; Zhang, G.; Pan, J.; Wang, Y.; Int. J. Biol. Macromol. 2014, 64, 213.

33. Murugesu, S.; Ibrahim, Z.; Ahmed, Q. U.; Uzir, B. F.; Yusoff, N. I. N.; Perumal, V.; Abas, F.; Shaari, K.; Khatib, A.; J. Pharm. Anal. 2019, 9, 91.

34. Inthongkaew, P.; Chatsumpun, N.; Supasuteekul, C.; Kitisripanya, T.; Putalun, W.; Likhitwitayawuid, K.; Sritularak, B.; Rev. Bras. Farmacogn. 2017, 27, 480.

35. Fabre, N.; Rustan, I.; Hoffmann, E.; Quetin-Leclercq, J.; J. Am. Soc. Mass Spectrom. 2001, 12, 707.

36. Santana, J. S.; Sartorelli, P.; Lago, J. H. G.; Quim. Nova 2012, $35,2245$.

37. Adfa, M.; Hattori, Y.; Ninomiya, M.; Funahashi, Y.; Yoshimura, T.; Koketsu, M.; Nat. Prod. Res. 2013, 27, 270.

38. Bandeira, P. N.; Pessoa, O. D. L.; Trevisan, M. T. S.; Lemos, T. L. G.; Quim. Nova 2002, 25, 1078.

39. Tusevski, O.; Krstikj, M.; Stanoeva, J. P.; Stefova, M.; Simic, S. G.; S. Afr. J. Bot. 2018, 117, 301.

40. Kumari, A.; Yadav, S. K.; Pakade, Y. B.; Kumar, V.; Singh, B.; Chaudhary, A.; Yadav, S. C.; Colloids Surf., B 2011, 82, 224.

41. Liu, X.; Zhu, L.; Tan, J.; Zhou, X.; Xiao, L.; Yang, X.; Wang, B.; BMC Complementary Altern. Med. 2014, 14, 12.

42. Volpe, C.; Villar-Delfino, P. H.; Anjos, P.; Nogueira-Machado, J. A.; Cell Death Discovery 2018, 9, 119.

43. Dick, M. K.; Miao, J. H.; Limaiem, F.; Histology, Fibroblast; StatPearls Publishing, 2019, available at https://www.ncbi.nlm. nih.gov/books/NBK541065/, accessed in June 2021.

44. Jose, G. M.; Raghavankutty, M.; Kurup, G. M.; J. Bioact. Compat. Polym. 2019, 34, 150.

Submitted: March 5, 2021

Published online: June 21, 2021 